\title{
Diferenças ultra-estruturais entre bexigas natatórias de peixes teleósteos de respiraçào aquática e respiração aérea facultativa
}

\author{
Carminda da Cruz-Landim (") \\ Maria Alice da Cruz-Höfling ("*)
}

\begin{abstract}
1 Resumo
O presente trabalho refere-se às diferenças ultraestruturaıs entre a bexiga natatória do jeju (teleósteo de respiração aérea facultativa) e do aruanã (teleósteo de respiração exclusivamente aquática ou branquial). Histologicamente, em ambos os casos, a parede da bexiga natatória se mostrou constituída por um epitélio, limitando a luz, com uma lâmina própria de tecido conjuntivo muito rico em colágeno, seguida de uma camada de musculatura lisa e uma adventícia. Os resultados sugerem que a adaptação à função respiratória na bexiga natatória do jeju refletem-se na diminuição da espessura da cobertura epitelial da câmara posterior. na presença desse epitélio de possíveis substâncias surfactantes que são eliminadas para a luz e na grande vascularizaçāo subepitelial.
\end{abstract}

INTRODUÇÃ̄o

A bexiga natatória dos peixes teleósteos é embriologicamente derivada do trato digestivo e em alguns peixes é mantida uma comunicação com ele através de um ducto pneumá tico graças ao qual é regulado o volume do gás no interior do órgão (bexigas natatórias fisóstomas). Em muitos peixes teleósteos esta comunicação se perdeu e a bexiga natatória passou a ser um órgão fechado, (bexiga fisóclita) onde o gás é secretado por uma glândula constituída de um epitélio secretor associado a uma rede capilar muito desenvolvida ("rete mirabile"). Muitos fisóstomos também possuem o sistema glandular "rete mirabile" para a secreção de gás. (Jones \& Marshall, 1953).

Pensa-se que a bexiga natatória tenha se originado, nos peixes, inicialmente como um órgão respiratório, embora nas espécies mais recentes ela sirva principalmente como órgão hidrostático. Em um certo número de espé- cies de teleósteos sul americanos, contudo, a bexiga natatória readquiriu, secundariamente, a função respiratória (Carter, 1957).

$\mathrm{O}$ objetivo deste trabalho é justamente fazer um estudo dos aspectos ultra-estruturais da bexiga natatória, principalmente os relacionados ao epitélio, que possam ser relevantes para o desempenho da função respiratória, em contraposição aos do órgão funcionando apenas como regulador da flutuação do peixe.

Existe um acervo relativamente grande de literatura a respeito da morfologia e fisiologia da bexiga natatória, sendo provavelmente uma das revisões mais recentes a de Fänge (1976).

No que concerne aos aspectos que serão abordados neste trabalho existem dados precursores de Hughes (1966 e 1973); Johansen (1970); Brooks (1970); Jásinski \& Kilarski (1969 e 1972); Phleger \& Saunders (1978); tiughes \& Weibel (1978). Em trabalho recente (Cruz-Höfling et al., s/d) foram estudadas comparativamente a histologia e a histoquímica das espécies objeto do presente relato. Os resultados tanto histológicos como histoquímicos, revelam diferenças marcantes entre as bexigas natatórias das duas espécies.

\section{MATERIAL E MÉtodos}

Foram utilizadas bexigas natatórias de Osteoglossum bicirrhosum (aruanā) peixe com respiração inteiramente aquática e Hoplerythrinus unitaeniatus (jeju), espécie de respiração aérea facultativa. Os espécimens foram pescados durante a expedição amazônica do R/V Alpha-Helix em janeiro de 1977 no rio Solimões.

(") - Instituto de Biociências - UNESP - Rio Claro, SP.

${ }^{(* *)}$ - Instituto de Biologia - UNICAMP - Campinas, SP. 
As bexigas natatórias foram dissecadas 3 fragmentos representativos foram fixados em glutaraldeído a $2,5 \%$ em tampão fosfato 0,2 $\mathrm{M} \mathrm{pH} \mathrm{7,2} \mathrm{durante} \mathrm{a} \mathrm{noite} \mathrm{a} 4^{\circ} \mathrm{C}$. A pós-fixação foi feita em ácido ósmico a $1 \%$ no mesmo tampão e teve duração de 2 horas, a $40^{\circ} \mathrm{C}$. Durante a desidratação foi feita contrastação com acetato de uranila a $1 \% \mathrm{em}$ álcool $90 \%$, banho que foi prolongado para 12 horas. A inclusão foi feita em araldite e os cortes obtidos com o ultramicrótomo Porter. Blum MT-2 com navalhas de vidro. Os cortes foram contrastados adicionalmente com acetato de uranila e citrato de chumbo.

\section{REsultados E Discussão}

Os peixes estudados apresentam bexigas natatórias com aspecto ultra-estrutural bastante diferente, mormente no que concerne ao epitélio e lâmina própria subjacente.

0 jeju, peixe de respiraçăo aérea opcional, apresenta a bexiga dividida em duas câmaras distintas por um estrangulamento mediano. A câmara anterior tem paredes finas e pouco vascularizadas, enquanto a posterior as tem mais espessas e mais vascularizadas.

$\mathrm{O}$ epitélio da câmara anterior é formado por células altas (Fig. 1a) ou cúbicas (Fig. 1b) nitidamente polarizadas, principalmente as primeiras. Um retículo endoplasmático granular relativamente bem desenvolvido ocupa a porção basal da célula. O núcleo, de forma irregular com cromatina condensada na periferia, localiza-se na zona mediana, enquanto a porção apical é ocupada por mitocôndrios, complexo de Golgi e grânulos de secreção. Os grânulos consistem de um core muito eletrondenso de forma irregular, imerso em matriz de pequena densidade que às vezes aparece como um halo parcial ao seu redor (Fig. $1 b$ e $2 b$ ). Cortes periféricos de tais grânulos mostram material de baixa densidade eletrônica contido dentro de um envoltório membranoso (Fig. 1a e 2b). A membrana plásmica entre as células vizinhas é muito sinuosa e o fato de se apresentar com tendência a ser paralela à superfície nas células mais baixas, parece indicar que as células podem variar

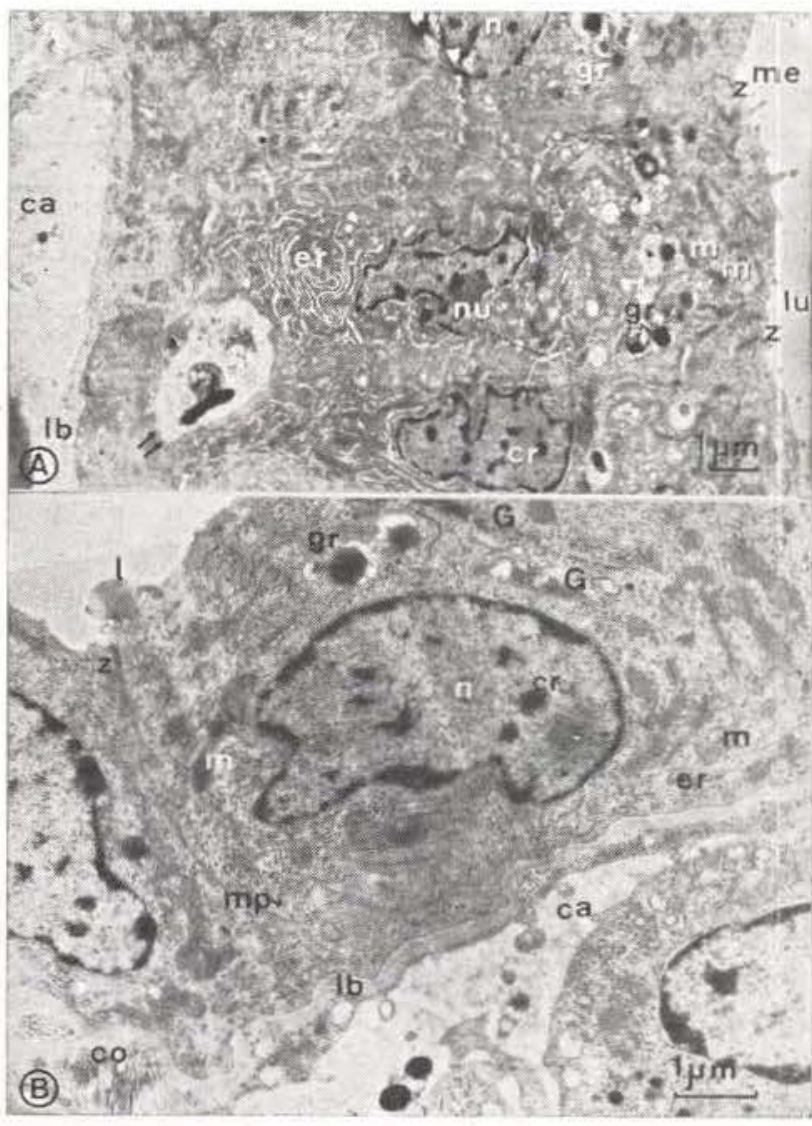

Fig. 1 - Epitélio da câmara anterior da bexiga natatória de $\mathrm{H}$. unitaeniatus. A) epitélio cilíndrico. As flechas indicam leucócito. A] epitélio cúbico. A flecha indica dilatação do espaço intercelular. lu=lúmen; $m e=e s-$ truturas membranosas; $z=$ zônula de oclusão; $n=$ núcleo; $\mathrm{cr}=$ cromatina; er=retículo endoplasmático granular; $\mathrm{m}=$ mitocôndrios; $\mathrm{gr}=$ grânulos de secreção; $\mathrm{nu}=\mathrm{nu}$ ciéolo; lb=lâmina besal; $\quad c a=$ capilar; $\mathrm{mp}=$ membrana plásmica; $\mathrm{G}=\mathrm{Golgi} ; \mathrm{co}=$ colágeno; $\mathrm{I}=$ lípidios .

sua altura com o grau de distenção do órgão (Fig. 1b); na porção apical as membranas contactantes mostram zônulas de oclusão fechando o espaço intercelular, embora na porção mediana e basal os espaços possam se apresentar dilatados indicando a possibilidade de transporte por essa (Fig. 2a). Este epitélio apresenta raras microvilosidades, bastante curtas (Fig. 1a e 2a) e algumas vesículas pequenas nesta zona podem indicar alguma atividade pinocítica (Fig. 2a).

A lâmina basal deste epitélio é relativamente espessa e abaixo desta, feixes de fibras colágenas aparecem em quantidade (Fig. 1b). 


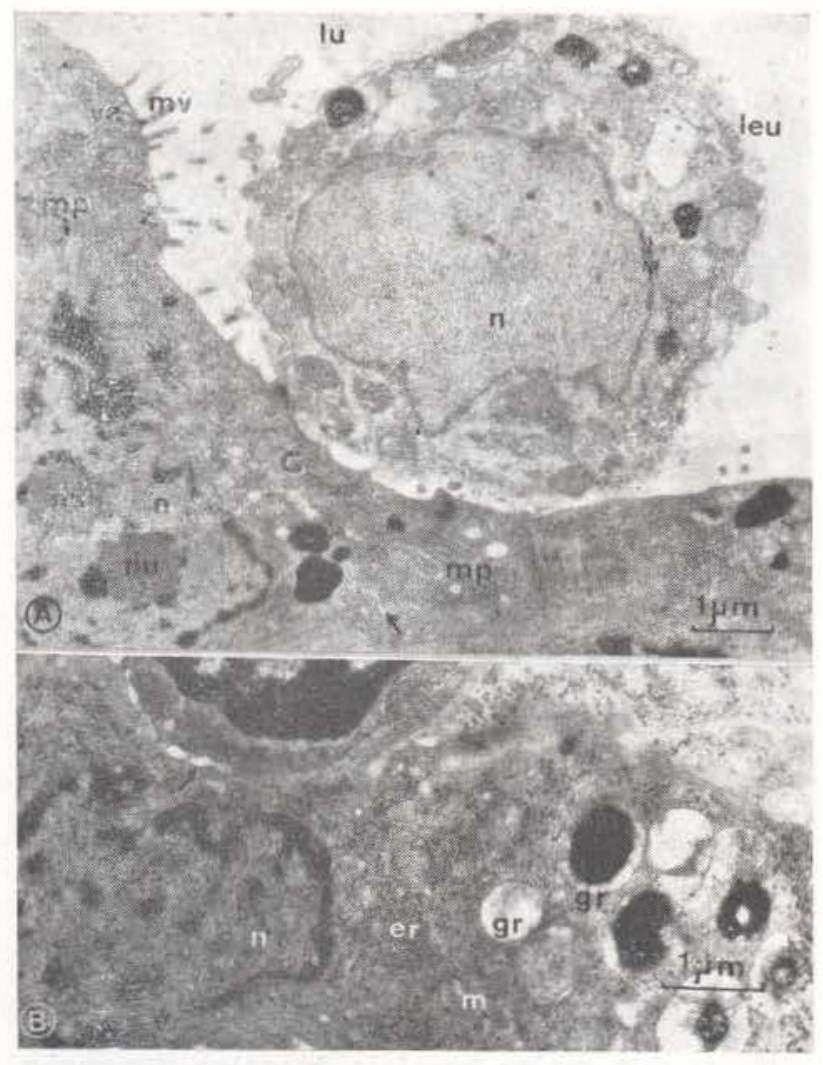

Fig. 2A - Câmara anterior da bexiga de H. unitaeniatus vendo-se um leucócito (leu) na luz (lu), 2B - Detalhe de produtos de secreção (gr) das células. As flechas indicam o espaço intercelular alargado. $\mathrm{n}=$ núcleo; z=zônula de oclusâo; nu=nucléolo; $\mathrm{cr}=$ cromatina er $=$ retículo endoplasmático granular; $\mathrm{mv}=$ microvilosidades.

Capilares de pequeno calibre são freqüentes logo abaixo do epitélio, havendo evidências de que leucócitos podem atravessar a camada epitelial (Fig. 1a) caindo no lúmen da bexiga. (Fig. 2a).

O epitélio da câmara posterior apresenta. se constituído de células pavimentosas, entre as quais os contactos são mais sinuosos. Essas células apresentam-se mais ricas em microvilosidades (Fig. 3a, b e c) e apresentam além dos grânulos já descritos, (Fig. 4a) grânulos citoplasmáticos com estrutura lamelar (Fig. $3 \mathrm{C}$ ), os quais se assemelham às estruturas descritas em pulmões de mamíferos, répteis, anfíbios e aves com o nome de citossomas (Broôks, 1970 b), e também presente em peíxes (Brooks, 1970 a) além de grânulos osmio. fílicos (Fig. 3a e 3b) sem estrutura lamelar.
$\mathrm{Na}$ luz dessa porção da bexiga são comuns grandes esferas de densidade eletrônica variável (Fig. 3b e 4b). Podem ser vistas junto a eles estruturas membranosas, as quais também podem ser observadas junto ao epitélio de revestimento, com aspecto de bolhas (Fig. 3b, 4b e 4c). Copeland (1969) considera os corpos densos, ou citossomas, como envolvidos com a secreção de gás em mamíferos. Sugere também sua origem a partir do Golgi onde conteriam surfactantes destinados a reduzir a tensão superficial dos alvéolos pulmonares. Dada a semelhança morfológica entre os citossomas de mamíferos e de peixes, é possível que haja também correlação funcional entre eles. Por outro lado, são também atribuidas aos citossomas funções antioxidantes, para proteção dos alvéolos contra os efei-

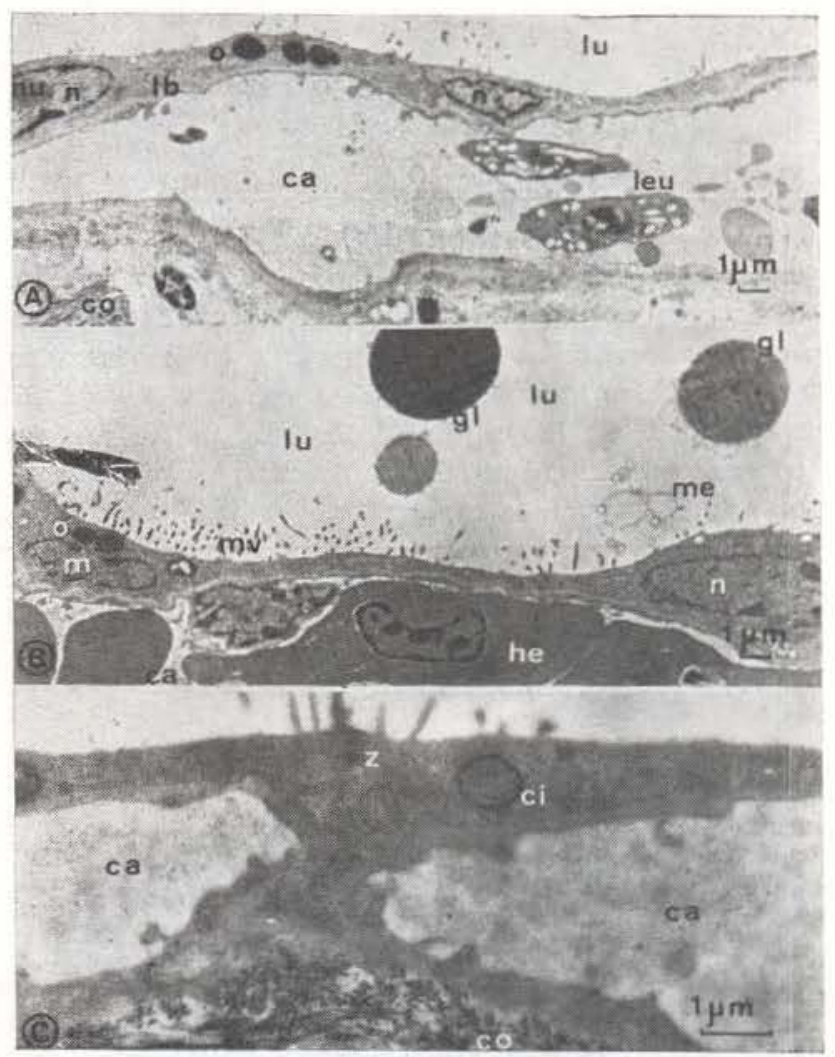

Fig. 3 - Epitélio da câmara posterior da bexiga natatória de $\mathbf{H}$. unitaeniatus. A) células baixas com grânulos osmiófilos (o) e vescularização subjacente (ca). B) glóbulos esféricos ( $\mathrm{gl}$ ) e estruturas membranosas (me) na luz (lu). C) célula com citossoma (ci). co=colágeno. $\mathrm{lb}=$ =âmina basal; he=hemácia; leu=leucócitos, $\mathrm{mv}=$ microvilosidades. 


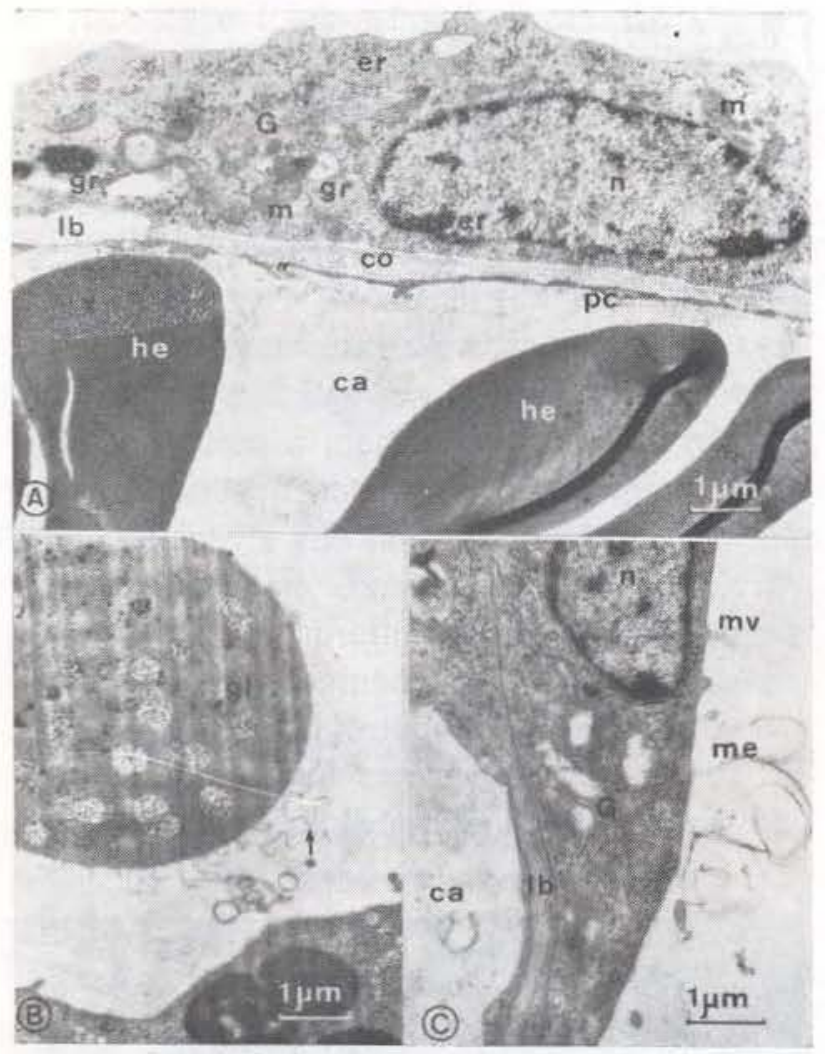

Fig. 4 - Câmara posterior da bexiga natatória de $\mathbf{H}$. unitaeniatus. A) aspecto detalhado da célula epitelial; B) Detalhe de um glóbulo esférico mostrando a estrutura membranosa na periferia (flecha). C) Aspectos da estrutura membranosa (me) junto ao epitélio. $m=m i-$ tocôndrios; $\quad \mathrm{G}=$ Golgi; $\quad \mathrm{lb}=$ lâmina basal; $\mathrm{n}=$ núcleo; $\mathrm{co}=$ colágeno; $\mathrm{pc}=$ parode do capilar; he=hemácia; o= grânulo osmiófilo; ca=capilar .

tos tóxicos de alto teor de oxigênio (Copeland, 1969, Brooks, 1970 b).

É sabido que as substâncias surfactantes são compostas de água, lipídios e proteínas (Brown, 1964). Estudos histoquímicos realizados na bexiga natatória de $H$. unitaeniatus revelaram a presença de mucopolissacarídeos ácidos e lipídios tanto no epitélio como subepitelialmente (Cruz-Höfling et al., s/d). Estes resultados $\mathrm{e}$ as observações ultraestruturais sugerem uma possivel relação entre essas substâncias, os citossomas e as meni. branas ou esferas presentes no lúmen. Os lipídios presentes na bexiga natatória teriam também funçāo hidrofóbica ou na remoção de impurezas trazidas pelo ar nos peixes de respiração aérea (Phleger \& Saunder, 1978).
A principal diferença entre a câmara posterior da bexiga natatória e a anterior referese à estrutura do epitélio que acaba de ser descrita e à riqueza muito maior em capilares subepiteliais (Fig. 3 e 4). Supõe-se, por estas características, que a câmara posterior seja a que funciona mais ativamente na troca de gases com o ar atmosférico, enquanto a anterior tem, segundo Kramer (1978), função importante no processo ventilatório.

$\mathrm{O}$ aruanã é um peixe de respiração exclusivamente aquática. A sua bexiga natatória apresenta paredes muito finas e transparentes nas quais a vascularização não se apresenta especialmente desenvolvida.

A camada epitelial desta bexiga apresenta constituição bastante diversa do anteriormente descrito. Em toda extensão da bexiga, as células apresentam-se de altura irregular. a qual aumenta na região do núcleo (Fig. 5a) e estreita-se lateralmente a este. O núcleo é alongado mas, singularmente não se coloca com o eixo maior paralelo à maior dimensão da célula como é usual; ao contrário, tem posição perpendicular, o que faz com que a célula se aprofunde na lâmina própria na região do núcleo (Fig. 5a e b). As células apresentam-se ricas em ribossomas mas pobres em membranas do retículo e outros orgânulos citoplasmáticos. Apresentam grânulos elípticos de grande densidade eletrônica, distribuídos preferencialmente na superfície apical. A superfície apical das células se projeta em numerosas microvilosidades curtas e grossas suportadas por filamentos que se prolongam para o citoplasma subjacente (Fig. 5b). Este epitélio apresenta-se aparentemente mais firmemente aderido à lâmina própria subjacente que o anteriormente descrito para o jeju, como parecem indicar as projeções da porção basal das células para o seu interior (Fig. 5a). Este epitélio apresenta-se dobrado, mesmo na bexiga distendida.

Além da estrutura diferente do epitélio, é flagrante a ausência de capilares subepiteliais nesta bexiga natatória em contraposição à do jeju.

A maior adesão entre o epitélio e a lâmina próprịa, bem como as dobras do epitélio 

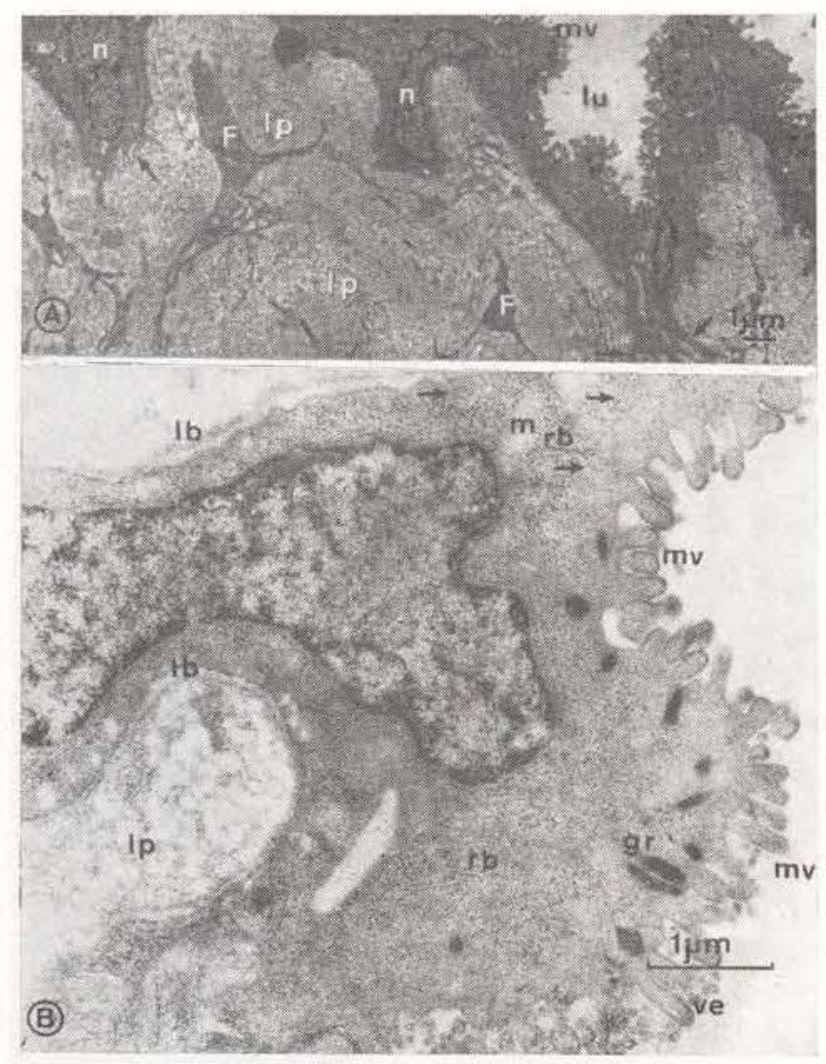

Fig. 5 - Epitélio da bexiga natatória de $\mathbf{0}$. bicírrhosum. A) Vista geral do epitélio vendo-se a maior $\epsilon$ spessura da célula na região do núcleo (n) e o imbricamento com a lâmina própria (lb) (flechas). B) Detalhe da célula vendo se as fibrilas apicais (Flechas). lu=luz; $m v=m i-$ crovilosidades; $\mathrm{gr}=$ grânulos; $\mathrm{rb}=$ ribossomas; $\mathrm{lb}=$ lâmina basal; ve=vesículas; $\mathrm{cr}=$ cromatina; $\mathrm{m}=$ mitocôndrios; $f=$ fibroblasto.

podem ser interpretadas como adaptação à função hidrostática deste órgão onde haveria forças mecânicas atuando durante a alteração de volume do órgão para a mudança de profundidade do peixe.

Histologicamente as bexigas natatórias estudadas são semelhantes. Suas paredes são constituídas por um epitélio limitando a luz, seguido de uma lâmina própria, capas de musculatura lisa, e adventícia, contudo, existem diferenças estruturais no arranjo dos componentes.

As lâminas próprias, como os epitélios, diferem nos dois tipos de bexigas. No jeju a lâmîna própria é ricamente vascularizada, prıncipalmente na câmara posterior e também apresentam bastante colágeno, já no aruanã a lâmina própria aparentemente não apresenta colágeno (Fig. 5a). Por outro lado também não apresenta vascuralização, é mais rica em fibroblastos com forma estrelada e grande parte da substância intersticial apresenta-se sob a forma de vesículas de baixa densidade eletrônica, que podem ser constituídas por lipidios (Fig. 5). Por outro lado também não apresenta vascularização, é mais rica em fibroblastos com forma estrelada e grande parte da substância intersticial apresenta-se sob a forma de vesículas de baixa densidade eletrônica, que podem ser constituídas por lipídios (Fig. $5 \mathrm{a}$ e b). Além disso, a lâmina própria é muito mais espessa no jeju, que no aruanã.

O colágeno da lâmina da bexiga do jeju apresenta-se em fibras finas logo abaixo do epitélio e em fibras muito grossas nas ca-

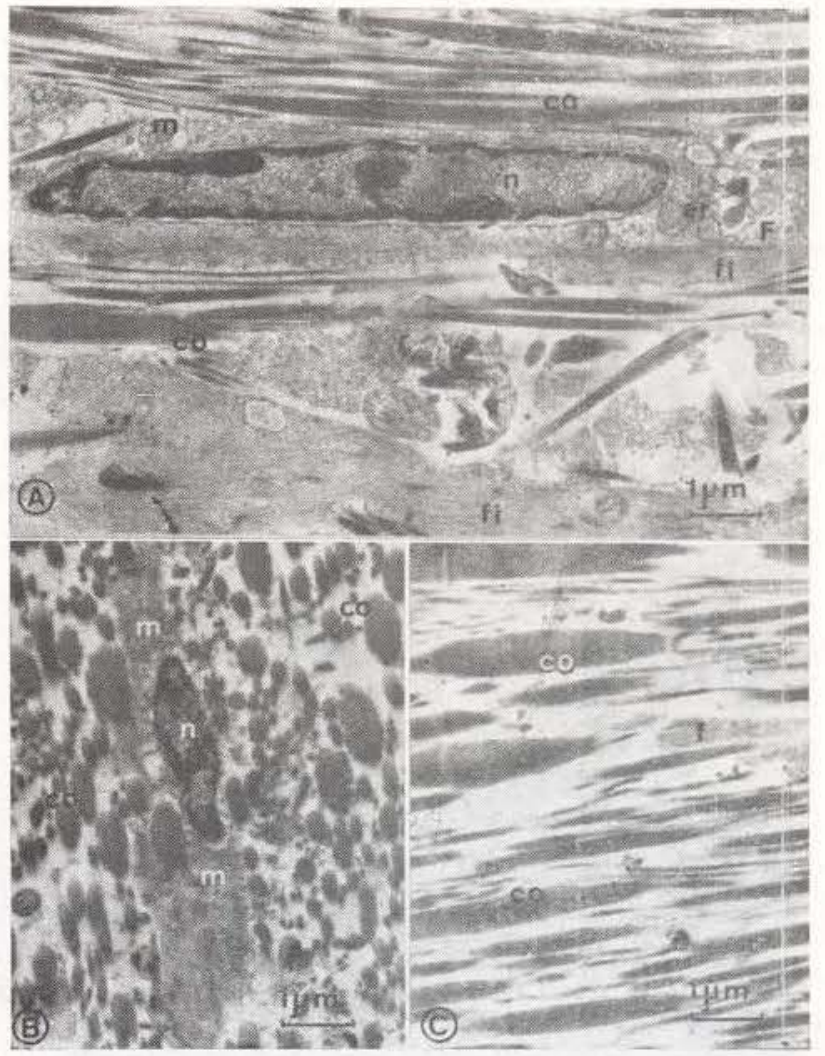

Fig. 6 - Lâmina própria subcapilar de H. unitaeniatus A) Fibroblasto $(F)$ e colágeno $(\mathrm{CO})$. Corte tránsversal das fibras colágenas grossas (co). Corte obliquo das mesmas fibras (co). $n=$ núcleo; $m=$ mitocôndrios; er =retículo endoplasmático; $\mathrm{fi}=$ fibrilas finas sem estrutura. 
madas mais profundas as quais podem ser observadas na Figura 6 em cortes longitudi. nais transversais; há também fibroblastos muito alongados (Fig. 6a) e fibrilas muito finas e sem estruturação, provavelmente precursoras das fibras colágenas. Algumas células cheias de grânulos que aparecem nessa zona podem ser mastócitos (Fig. 7a).

As capas musculares não apresentam diferenças nas duas espécies estudadas (Fig. 7b) a não ser pelo seu maior desenvolvimento no jeju. Tal fato pode ser atribuído à necessidade de ganho de eficiência na absorção de gás por um órgāo que se adaptou à respiração aérea. Trata-se de fibras musculares lisas não muito alongadas e bem separadas entre si por tecido conjuntivo rico em colágeno.

A adventícia volta a apresentar diferenças. O tecido conjuntivo é mais espesso no

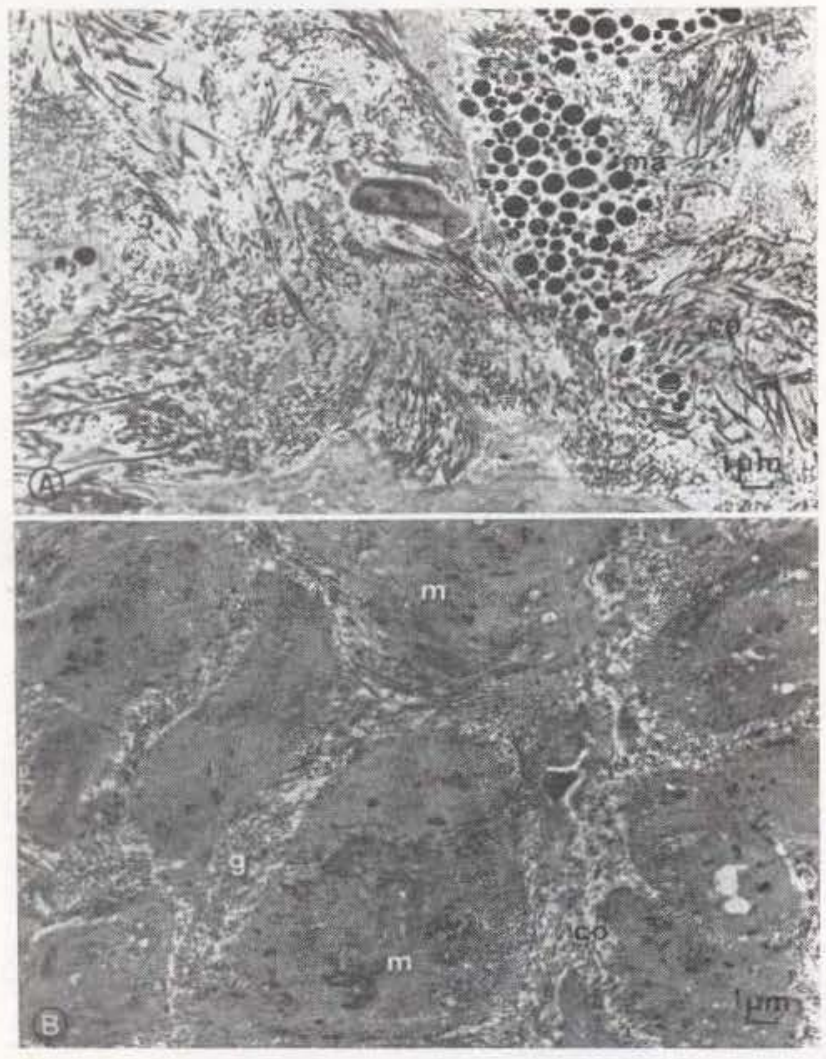

Fig. 7A - Lâmina própria de $\mathbf{H}$. unitaeniatus mostrando fibras colágenas $(\mathrm{co})$ mais finas e possível mastócito (ma). 7B - Musculatura lisa de 0 . bicirrhosum em corte transversal; $\mathrm{m}=$ célula muscular; $\mathrm{co}=$ colágeno; $\mathrm{F}=$ fibroblasto. aruanã e é relativamente comum a presença de nervos no seu interior (Fig. 8a). Já no que diz respeito ao jeju, a adventícia restringe-se quase exclusivamente à serosa que faz o fechamento da parede do órgão do lado exter. no (Fig. 8b).

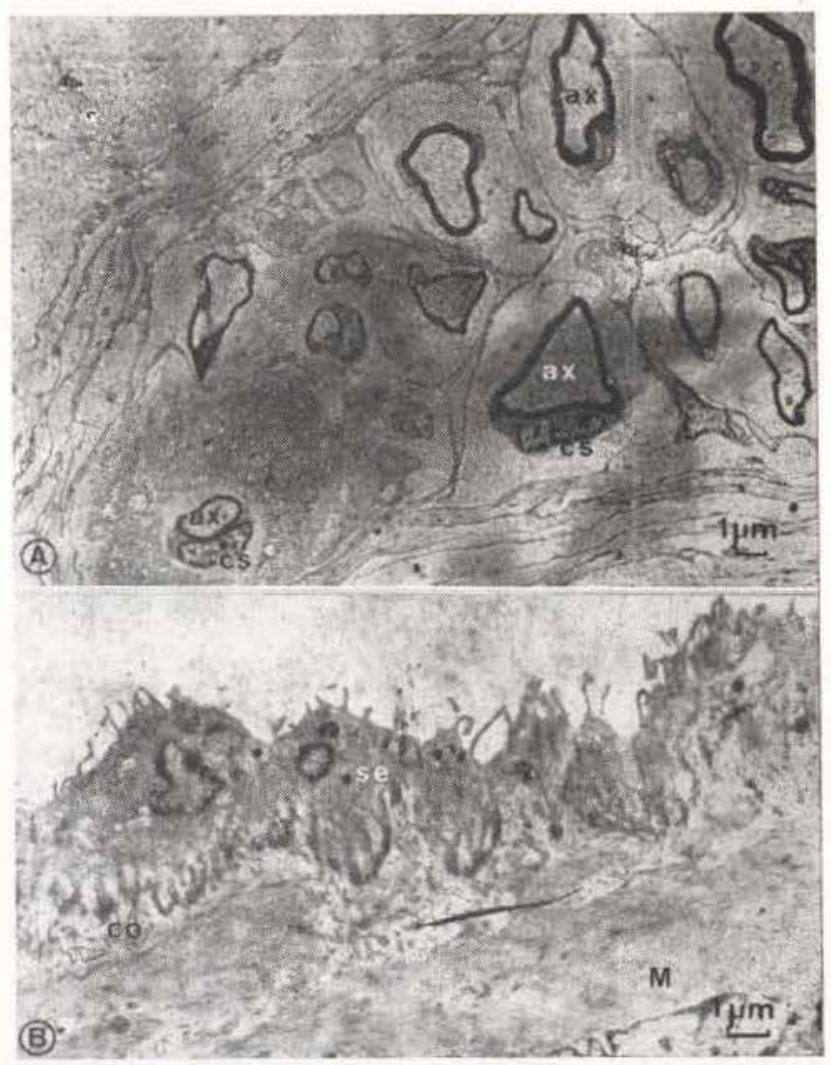

Fig. $8 \mathrm{~A}$ - Adventícia de 0 . bicirrhosum mostrando a serosa que limita externamente o órgăo. 8 B - Adventícia de $\mathbf{H}$. unitaeniatus mostrancio a serosa (se) que limita externamente o órgão. cs=célula de Schwann. $\mathrm{ax}=$ axônio; $\mathrm{M}=$ célula muscular; $\mathrm{co}=$ colágeno .

\section{CONCLUSÕES}

As bexigas natatórias das espécies estudadas são histologicamente semelhantes, mas apresentam diferenças estruturais na organização e grau de desenvolvimento dos tecidos componentes.

As duas espécies estudadas diferem na função desempenhada pela bexiga natatória. No jeju, a bexiga, ao lado da função hidrostática, desempenha também a função de órgão respiratório, enquanto no aruanã é apenas um órgão hidrostático. As diferenças encontra- 
das parecem refletir adaptações às funções desempenhadas: são óbvias aquelas representadas pela alta vascularização subepitelial, o epitélio muito baixo e as evidências de possíveis substâncias surfactantes na câmara posterior do jeju. Adaptações menos óbvias são as representadas pelas diferenças de estrutura da lâmina própria e da adventícia, bem como do grau de desenvolvimento da musculatura Jones \& Marshall (1953).

\section{Agradecimentos}

Agradecemos ao $\mathrm{Dr}$. Naércio Menezes e Dr. Heraldo Britski do Museu de Zoologia da USP, a identificação das espécies utilizadas no presente trabalho. A pesquisa foi possivel graças ao auxílio do CNPq e do NSF Grant. n. BNS75-10457 AO1.

\section{SUMMARY}

The present paper demonstrates the ultrastructural differences between the swimbladder of two teleostean fishes with different breathing behavior the jeju a facultative air breathing fish) and the aruanã (exclusively water breathing). Histologically both swimbladders are very similar. Their walls consist of an epithelium, its lamina propria, the muscular sheaths and the adventícia. The results suggest that the respiratory adaptations of the jeju swimbladder are characterized by a decreased height of the epithelium in the posterior chamber, the presence of surfactants in the lumen and increased subepithelial vascularization.

\section{BIBLIOGRAFIA}

BROOKS, R.

$1970 \mathrm{a}$ - Ultrastructure of the physostomatous swimbladder of rainbow trout (Salmo gairdneri). Z. Zellforsch, $106: 473-483$.

1970b - Lung alveolar cell cytosomes: a consideration of their significance. Z. Zeliforsch. $106: 484-497$.

Brown, E.S.

1964 - Isolation and assay of dipalmitoyl lecithin in lung extracts. An. J. Physiol., 207 : 473-483.

CARTER, G.S.

1957 - Air breathing. In: Physiology of fishes. Vol. I Metabolism. Ed. M.E. Academic Press, N.Y. pp. 65-79
Copeland, E.D.

1969 - Fine structural study of gas secretion in the physoclistous swim bladder of Fundulus heteroditus and Gadus callarias and in the euphysoclistous swim bladder of Opsanustau. Z. Zellforhsch., $55: 849-912$.

Cruz-Höfling, M.A.; Cruz-Landim, C. \& Patelli, A. s/d - Comparações morfológicas e histoquímicas de bexigas natatórias de peixes teleósteos de respiração aquática e respiração aérea. Não publicado.

FÄNGE, R.

1976 - Gas exchange in the swimbladder. In. Respiration of amphibious vertebrates. Ed. by G.M. Hughes. Academic Press. London. pp. 189-211.

Hughes, G.M.

1966 - Evolution between air and water. Ciba foundation Symp. on Develop. of lung (ed. de Reuck and Porter) - Churchill Ltda., London, pp. 64-80.

1973 - Ultrastructure of the lung of Lepidosiren and Neoceratodus in relation to the lung of other vertebrates. Folia Morph., Phana, $21: 155-161$.

Hughes, G.M. \& Weibel, E.R.

1978 - Visualization of layers lining the lung of the south american lugfish (Lepidosiren paradoxa) and a comparison with the frog and rat. Tissue and Cell, $10: 343-353$.

KRAMER, D.L.

1978 - Ventilation of the respiratory gas bladder in Hoplerythrinus unitaeniatus (Pisces, Characoidei, Erythrinidae). Can. J. Zool.. $56:$ 931-938.

JÁSINSKI, A. \& KILARSKI, W.

1969 - On the fine structure of the gas gland in some fishes. Z. Zellforsch, 102:333-356.

1972 - Gas secretion cells in the rear chamber of the swimbladder of the pond-loach, Misgurnus fossilis. L. Z. Zellforsch.. 134 : 273-282.

JOHANSEN, K.

1970 - Air breathing in fishes. In: Fish physiology. Vol. IV. Ed. W.S. Hoar and D.J. Randall. Academic Press, London.

Jones, F.R.H. \& Marshall, N.B.

1953 - The structure and functions of the teleostean swimbladder. Biol. Rev., 28: 16-83.

Phleger, C.F. \& Saunders, B.S.

1978 - Swim-bladder surfactants of Amazon air breathing fishes. Can. J. Zool., 56:946-952.

(Aceito pa:a publicação em $21 / 03 / 79$ ) 